\title{
REFREEZING OF INTERSTITIAJ WATER IN A SUBGLACIAL GAVITY OF AN ALPINE GLACIER AS INDICATED BY THE CHEMICAL COMPOSITION OF ICE
}

\author{
By R. A. Souchez, R. D. Lorrain and M. M. Lemmens \\ (Laboratoire de Géomorphologie, Faculté des Sciences, Université Libre de Bruxelles, \\ B ro5o Bruxelles, Belgium)
}

\begin{abstract}
With the aid of an atomic absorption spectrophotometer (Perkin Elmer 303), chemical analyses were performed on different types of ice collected in an enclosed natural subglacial cavity of the Glacier d'Argentière (French Alps). Contamination was reduced to background noise level of the instrument at each step of the procedure which was developed. One of the main problems encountered during the processing was the desorption of cations adsorbed on the surface of particles dispersed in the ice.

The mean composition in $\mathrm{Na}, \mathrm{K}, \mathrm{Ca}$ and $\mathrm{Mg}$ was established for glacier ice and for ice accretions hanging from the ceiling of the cavity or at the bedrock-glacier contact. The mean composition and the ratio $(\mathrm{Na}+\mathrm{K}) /(\mathrm{Ca}+\mathrm{Mg})$ of the ice accretions are higher than those of the glacier ice. This implies a refreezing of interstitial water which was enriched by desorption when, before refreezing, it was forced through the mud layer plastered at the base of the glacier.
\end{abstract}

RÉsumé. Preuves du regel de l'eau interstitielle dans une cavité sous-glaciaire d'un glacier alpin tirées de la composition chimique de la glace. Différents types de glaces prélevés dans une cavité sous-glaciaire naturelle du glacier d'Argentière (Alpes françaises) ont été analysés à l'aide d'un spectrophotomètre d'absorption atomique (Perkin Elmer 303). Les contaminations ont été réduites au niveau du bruit de fond de l'appareil de mesure et cela, à chaque étape de la prise et du traitement des échantillons. L'un des principaux problèmes rencontrés lors de ce traitement a été la désorption des cations adsorbés à la surface des particules dispersées dans la glace.

La composition moyenne en $\mathrm{Na}, \mathrm{K}$, Ca et $\mathrm{Mg}$ a été établie pour des échantillons de glace de glacier, de copeaux de glace pendant au plafond de la cavité et d'accumulations laches de cristaux situés au contact glacier-rocher. La concentration globale et le rapport $(\mathrm{Na}+\mathrm{K}) /(\mathrm{Ca}+\mathrm{Mg})$ des copeaux de glace et des accumulations lâches de cristaux sont plus élevés que ceux relatifs aux glaces de glacier. Cela implique un regel d'eau interstitielle enrichie par désorption. Ce phénomène se produit quand l'eau, avant de regeler, traverse la couche de boue qui tapisse la base du glacier.

Zusammenfassung. Regelation von Porenwasser in einem Hohlraum unter einem Alpengletscher, gezeigt anhand der chemischen Zusammensetzung des Eises. Verschiedene Eistypen, die aus einem natürlichen, eingeschlossenen Hohlraum unter dem Glacier d'Argentière (Franz. Alpen) entnommen worden waren, wurden mit Hilfe eines Teilchenabsorptionsspektrophotometers (Perkin Elmer 303) analysiert. In jedem Abschnitt des entwickelten Verfahrens wurden die Verunreinigungen auf das Niveau des Geräterauschens reduziert. Eines der Hauptprobleme war die Desorption der Kationen, die an der Oberfläche von im Eis verstreuten Partikeln angelagert waren.

Die Zusammensetzung der Salzsole und die mittlere Verteilung von $\mathrm{Na}, \mathrm{K}$, Ca und $\mathrm{Mg}$ wurden für des Gletschereis und für Eisbildungen an der Höhlendecke in der Kontaktzone zwischen Gletscher und Fels ermittelt. Die mittlere Verteilung und das Verhältnis $(\mathrm{Na}+\mathrm{K}) /(\mathrm{Ca}+\mathrm{Mg})$ der Eisbildungen sind grösser als die in der Salzsole des Gletschereises. Dies deutet nicht nur auf eine Regelation des Porenwassers hin, sondern auch auf eine Anreicherung durch Desorption, wenn Wasser vor dem Wiedergefrieren mit Partikeln der gefrorenen Schuttschicht am Grunde des Gletschers in Berührung gekommen war.

\section{INTRODUCTION}

During work by Electricité de France (EDF) to channel and collect melt waters beneath the Glacier d'Argentière in the French Alps, an enclosed natural subglacial cavity was discovered (Vivian, I97I). It was isolated from galleries excavated into the rock by watertight bulkheads.

The cavity is located on the lee slope of the Lognan rock bar which is situated $2 \mathrm{~km}$ from the glacier front at an altitude of about 2 I $75 \mathrm{~m}$ and under approximately $90 \mathrm{~m}$ of ice (Fig. I). Its size is variable; the height usually averages $2 \mathrm{~m}$. The floor consists of polished metamorphic rocks of the Mont Blanc Massif. A melt stream periodically runs locally on this floor, but the depth of water is never important in relation to the height of the cavity.

Owing to the setting up of a programme called "Glaciolab 1972", organized by Dr R. Vivian of the Université de Grenoble, we had the opportunity of visiting this subglacial cavity three times (in March, June and September 1972) and collecting different types of ice, in order to study their chemical composition. 


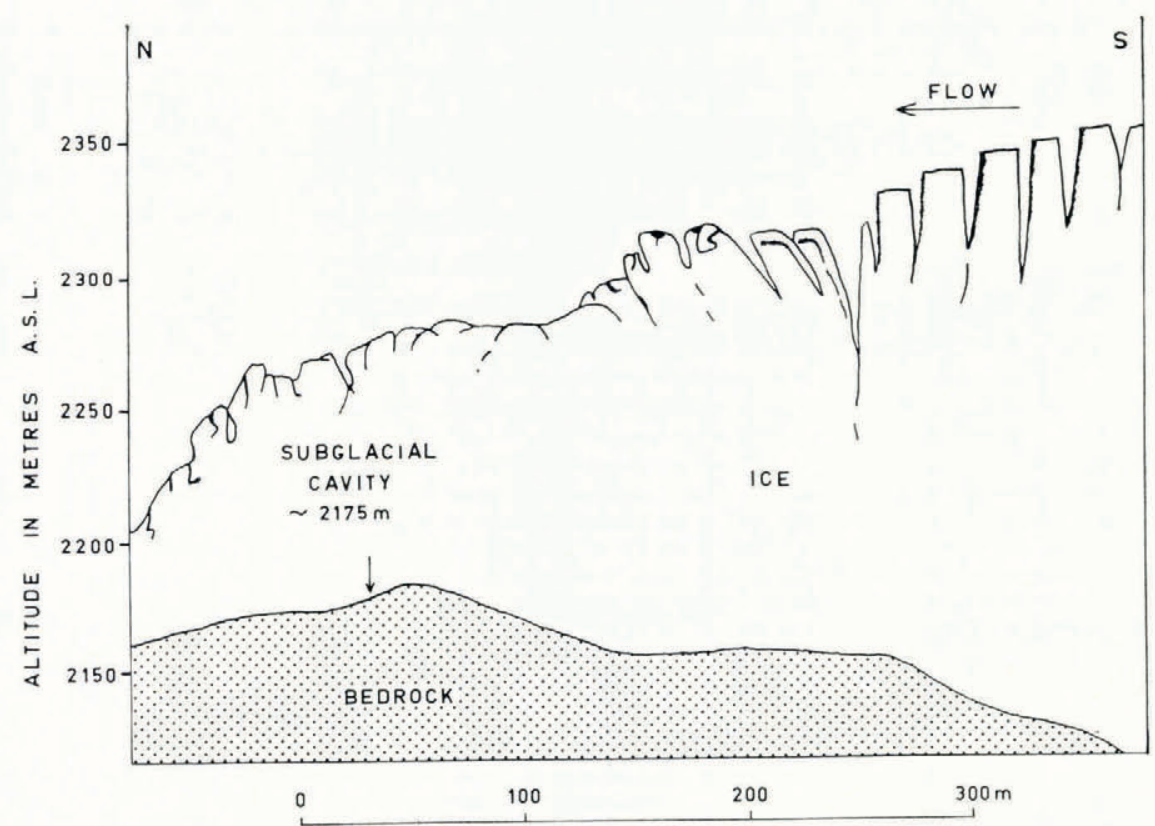

Fig. I. Longitudinal profile of the Glacier d'Argentière in the vicinity of the Lognan rock bar showing the location of the subglacial cavity where the ice samples were collected. (After R. Vivian, I97o.)

\section{DifFERENT TYPES OF IGE OBSERVED IN THE SUBGLACIAL CAVITY}

Four types of ice were distinguished:

(a) Ice accretions averaging ro $\mathrm{cm}$ in length and hanging from the ceiling of the subglacial cavity (Fig. 2).

(b) Ice accretions situated at the glacier-bedrock contact in the up-glacier part of the cavity (Fig. 3).

(c) Glacier ice with, at its base, a $2-3 \mathrm{~cm}$ thick layer of frozen mud.

(d) Stratified ice containing layers of fine rock particles, and located at the glacierbedrock contact in the down-glacier part of the cavity.

The glacier base at the ceiling of the cavity is not smooth, especially in the down-glacier part. There are protuberances, each of which contains a rock fragment. These fragments are progressively expelled from the glacier ice thus breaking the frozen mud layer. Ice accretions sometimes exist between the fragment and the mud layer (Fig. 4).

In this paper, we have paid attention to the first three types of ice mentioned above. The ice samples were analysed in liquid form for the major cations $\mathrm{Na}, \mathrm{K}, \mathrm{Ca}$ and $\mathrm{Mg}$ with a recorder-equipped Perkin Elmer 303 atomic absorption spectrophotometer.

\section{SAMPLING PROGEDURE}

Many precautions were taken in order to reduce contamination to the background noise level of the instrument, and to control chemical changes caused by the melting of the samples.

After removal of the ice surface exposed to the air, the ice samples were chipped off with the help of a chromium-vanadium steel chisel chosen after its lack of contamination in alkaline 


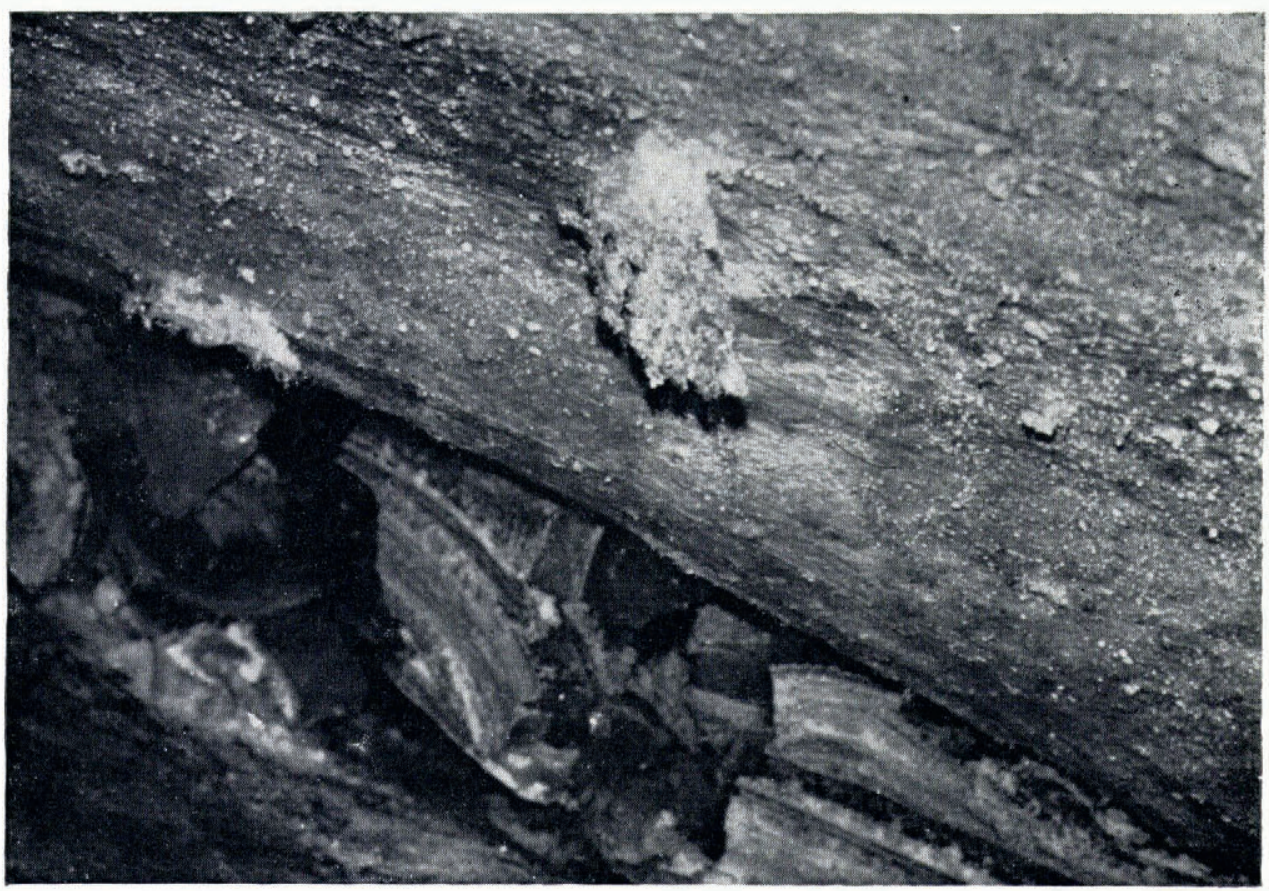

Fig. 2. Ice accretions hanging from the ceiling of the subglacial cavity. Glacier flow from left to right.

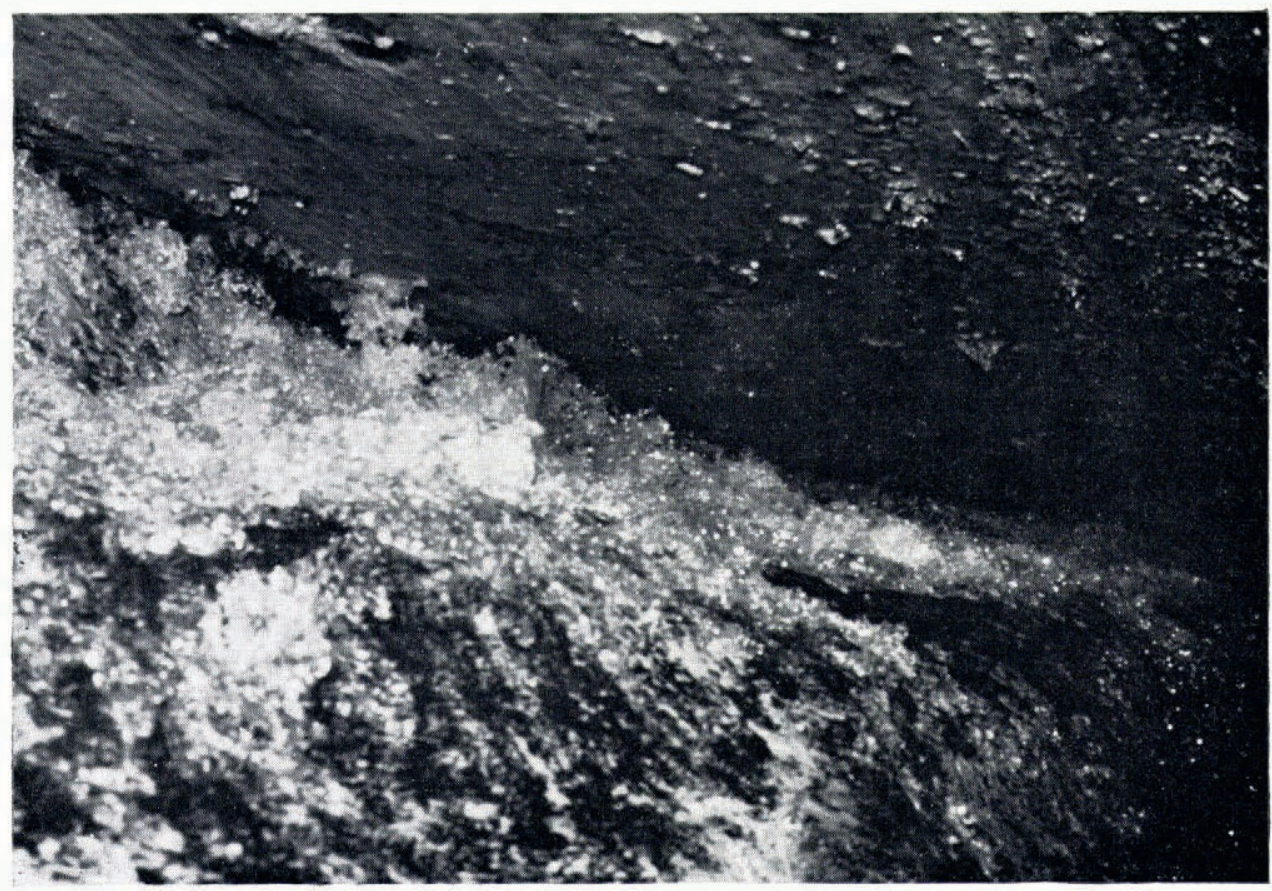

Fig. 3. Ice accretions situated at the glacier-bedrock contact in the up-glacier part of the cavity. Glacier flow from centre right. Height of the accretions about $20 \mathrm{~cm}$. 


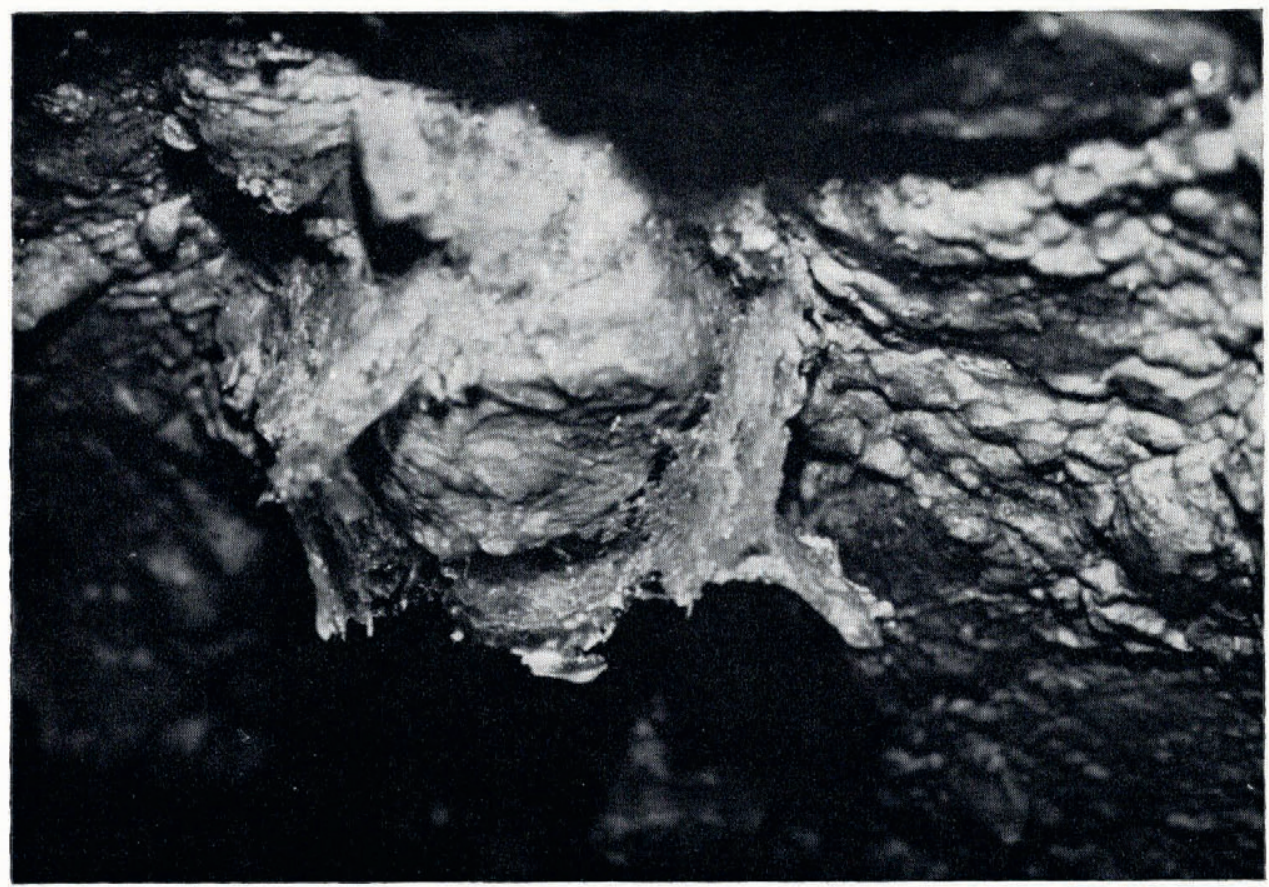

Fig. 4. Detail of one of the protuberances containing a rock fragment (IO cm long) at the ceiling of the subglacial cavity. Ice accretions can be observed between the rock fragment expelled from the glacier ice and the frozen mud layer which is plastered at the base of the glacier.

and alkaline-earth elements had been established in the laboratory. The samples were manipulated with clean polyethylene gloves - a new pair of gloves was used for each sample - and transferred into polyethylene containers which had been cleaned in the laboratory with a mixture of chemically pure nitric acid and detergent and then copiously rinsed with distilled water. The tightly closed polyethylene containers were placed in a thermally isolated box and then transferred to a room adjacent to the subglacial cavity for processing.

\section{SAMPLE TREATMENT}

In the treatment of the samples, one of the main problems encountered was related to the presence of particles in the ice. As the ice was melted, cations adsorbed on the surface of the particles were able to migrate into the solution. This desorption mechanism can greatly affect the results, depending on the quantity and size of the particles and on the time during which the particles are in contact with water. The adsorption concept is here used in its most general sense which includes adsorption and ion-exchange processes. To our knowledge, the influence of desorption on the chemical composition of temperate glacier ice during the processing of samples has not been much investigated. However, desorption may play a prominent role when the particle content of ice is higher than a few grams per kilogram. If samples are stored for a period of several days in liquid form, very small concentrations of particles may completely negate results.

In order to limit this effect, the following procedure was developed. After checking that no melting occurred during transfer of the samples from the subglacial cavity to the adjacent room, each sample container was locally heated in a suitable hot water-bath. This procedure permitted localized and quick melting of the ice. As soon as it was produced, ro ml of melt 
water was recovered with the aid of a polyethylene syringe. The water obtained in this way was then immediately press-filtered through cellulose acetate filters (pore diameter: $0.45 \mu \mathrm{m}$ ) and directly collected in polyethylene bottles previously cleaned in the laboratory using the method indicated above. The polyethylene syringes, polypropylene filtration assemblies and membrane filters were used only once. Laboratory tests had proved that all this apparatus did not contaminate the samples. The membrane filters were rinsed with distilled water immediately before being used. The time that elapsed between the appearance of the first melted drop to the completed filtering of $10 \mathrm{ml}$ of water was approximately $30 \mathrm{~s}$. Because of the important desorption phenomenon, even in such a short processing period, ice having a particle content higher than $10 \mathrm{mg} / \mathrm{IO} \mathrm{cm}^{3}$ (about $\mathrm{I} \mathrm{g} / \mathrm{kg}$ ) was not considered. For a few milligrams per Io $\mathrm{cm}^{3}$, in the case studied here, the comparison between $10 \mathrm{ml}$ immediately filtered samples with that of $10 \mathrm{ml}$ samples filtered $24 \mathrm{~h}$ later confirmed in each case that desorption did not play a significant role in the results.

Four successive ro $\mathrm{ml}$ filtered water samples were taken from each ice sample in such a way that particles were not in contact with the melt water for more than $30 \mathrm{~s}$. Each filtered sample was then immediately acidified to $\mathrm{pH}_{3}$ with chemically pure nitric acid in order to avoid adsorption of cations other than $\mathrm{H}^{+}$on the walls of the polyethylene bottles.

Independently, blocks of ice were taken and transferred into polyethylene containers and allowed to melt totally without any intervention. After melting was completed, the melt water was filtered and acidified. Only the samples with a particle content of less than $0.5 \mathrm{~g} / \mathrm{l}$ were considered. The results of the analyses on these blocks of ice supposedly represent the mean chemical composition of the ice samples in $\mathrm{Na}, \mathrm{K}, \mathrm{Ca}$ and $\mathrm{Mg}$.

\section{Results AND GOMMENTS}

A systematic decrease in $\mathrm{Na}, \mathrm{K}, \mathrm{Ca}$ and $\mathrm{Mg}$ content takes place from the first to the fourth filtered sample. This is connected with a dilution of the interstitial water which is mainly located at three- and four-grain intersections (Renaud, [1952]; Lliboutry, I97I; Nye and Frank, in press). Table I gives, for the four successive filtered samples, the mean values of the ratios $(\mathrm{Na}+\mathrm{K}) /(\mathrm{Ca}+\mathrm{Mg})$ and $\mathrm{Na} / \mathrm{K}$ for the two types of ice accretion, considered as a single group, compared with that of the glacier ice. It should be noted that both ratios decrease with progressive melting. This may be due to differential incorporation during ice formation but more research is needed in order to determine whether or not such an effect may play a part here (Jellinek, $\left[{ }^{\mathrm{C}} \mathrm{I} 972\right]$ ). It cannot be explained by selective diffusion. If this mechanism is the major factor, diffusion coefficients would control the trends of both ratios. Now, at $\mathrm{o}^{\circ} \mathrm{C}$, for infinite dilution, the diffusion coefficient is $\mathrm{I} .0 \times \mathrm{IO}^{-5} \mathrm{~cm}^{2} / \mathrm{s}$ for $\mathrm{K}^{+}$and $0.64 \times \mathrm{IO}^{-5} \mathrm{~cm}^{2} / \mathrm{s}$ for $\mathrm{Na}^{+}$. 'Thus the $\mathrm{Na} / \mathrm{K}$ ratio would increase with progressive melting, a situation which is the reverse of what is observed.

Table I. Mean values of the ratios $(\mathrm{Na}+\mathrm{K}) /(\mathrm{Ca}+\mathrm{Mg})$ and $\mathrm{Na} / \mathrm{K}$ for THE FOUR SUCCESSIVE IO Ml FILTERED SAMPLES

\begin{tabular}{lcccccccc} 
& \multicolumn{9}{c}{$(\mathrm{Na}+\mathrm{K}) /(\mathrm{Ca}+\mathrm{Mg}) *$} & \multicolumn{4}{c}{$\mathrm{Na} / \mathrm{K} *$} \\
Types of ice & $\mathrm{I}$ & 2 & 3 & 4 & $\mathrm{I}$ & 2 & 3 & 4 \\
Ice accretions & 4.27 & 3.90 & 3.30 & 3.30 & 1.05 & 1.04 & 0.99 & 0.97 \\
Glacier ice & $\mathrm{I.05}$ & 1.05 & 0.95 & 0.75 & 1.47 & 1.36 & 1.22 & 1.28
\end{tabular}

* Concentrations in the ratios are expressed in meq $\mathrm{l}^{-1}$. If expressed in $\mathrm{mmol} \mathrm{l^{-1 }}$, the $(\mathrm{Na}+\mathrm{K}) /(\mathrm{Ca}+\mathrm{Mg})$ ratio would double.

Table II gives the mean composition of the ice accretions compared with that of the glacier ice. The $(\mathrm{Na}+\mathrm{K}) /(\mathrm{Ca}+\mathrm{Mg})$ ratios are also included. It should be noted that the mean chemical composition values for the glacier ice (0.16 ppm Na; $0.22 \mathrm{ppm} \mathrm{K}$; $0.25 \mathrm{ppm} \mathrm{Ca}$ 
and $0.08 \mathrm{ppm} \mathrm{Mg}$ ) are relatively high if we compare them with the purer glacier ice we analysed from the base of the neighbouring Mer de Glace (o. 5 ppm Na; 0.08 ppm K; $0.10 \mathrm{ppm} \mathrm{Ca}$ and $0.04 \mathrm{ppm} \mathrm{Mg}$ ). It seems therefore that the history of the glacier ice appearing at the ceiling of the subglacial cavity of the Glacierd'Argentière is a complex one; the original glacier ice has very likely undergone a slight increase in the concentrations of the cations studied.

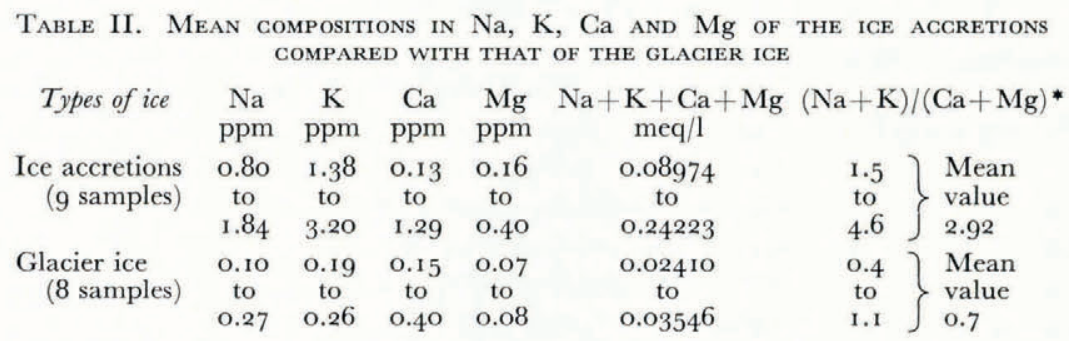

* Concentrations in the ratio are expressed in meq $1^{-1}$. If expressed in $\mathrm{mmol}^{-1}$, the quoted ratio would double.

A strikingly higher mean content of the ice accretions and a higher $(\mathrm{Na}+\mathrm{K}) /(\mathrm{Ca}+\mathrm{Mg})$ ratio can be observed. This higher mean content might be partially due to a difference in the size of ice crystals but the relatively large enrichment of $\mathrm{Na}$ and $\mathrm{K}$ in the accretions indicates that another factor has to be taken into account.

The ice accretions at the bedrock-glacier contact or at the ceiling of the cavity are in contact with particles at the base of the glacier. Adsorbed cations held on the surface of these particles desorb in this situation and diffusion of cations takes place along the interstitial channels. However, this phenomenon cannot alone explain the values for the $(\mathrm{Na}+\mathrm{K}) /$ $(\mathrm{Ca}+\mathrm{Mg})$ ratios. The alkaline cations adsorbed on the particles represent $3.8-6.0 \mathrm{meq} / \mathrm{roo} \mathrm{g}$ dry mud (ammonium acetate method), i.e. $35-42 \%$ of the four cations analysed. Giving time for diffusion, the resulting $(\mathrm{Na}+\mathrm{K}) /(\mathrm{Ca}+\mathrm{Mg})$ ratio would be lower than I or near this value.* This has been confirmed by desorption tests in the laboratory using melted glacier ice and particles of the mud layer which are free of carbonates. Therefore, the high values of the $(\mathrm{Na}+\mathrm{K}) /(\mathrm{Ca}+\mathrm{Mg})$ ratio for the ice accretions cannot be explained by such a diffusion mechanism.

If interstitial water is forced through the mud layer, the alkaline cations adsorbed on the particles will desorb more quickly and relatively more than the alkaline earths. When monovalent and divalent cations co-exist in such a system, the divalent ions in the "adsorbed" diffuse layer tend to be closer to the walls of the pores. Consequently, the average divalent ion is not carried down-stream as fast as the average monovalent ion (Kemper and others, 1970). Separation of cation species, as interstitial water flows through the mud layer, is an explanation for the substantial enrichment of $\mathrm{Na}$ and $\mathrm{K}$. Refreezing of this interstitial water at the ceiling of the cavity or at the bedrock-glacier contact gives rise to the ice accretions which are richer in alkalis than the glacier ice. Furthermore, we may consider the mean value I.05 for the $(\mathrm{Na}+\mathrm{K}) /(\mathrm{Ca}+\mathrm{Mg})$ ratio obtained from the first-filtered water samples for glacier ice (Table I) to be near the true ratio for the interstitial water. In this case, the higher $(\mathrm{Na}+\mathrm{K}) /(\mathrm{Ca}+\mathrm{Mg})$ ratio for the mean composition of the ice accretions (2.92 in Table II) also indicates the role of the invoked desorption.

\footnotetext{
* Concentrations in the ratio are expressed in meq $\mathrm{I}^{-1}$.
} 
An isothermal situation in itself does not prevent the refreezing of interstitial waters since the freezing point is pressure-dependent and since a topographic obstacle like a rock bar is able to produce pressure fluctuations at the base of a glacier.

In conclusion, the study of the chemical composition of the different types of ice found in the subglacial cavity of the Glacier d'Argentière has enabled us to indicate the occurrence, in a peculiar topographic situation, of ice formed by refreezing of interstitial water at the base of a temperate glacier.

\section{Acknowledgements}

The authors wish to express their gratitude to Dr R. Vivian of the Université de Grenoble for the opportunity given them to collect ice samples in the subglacial cavity of the Glacier d'Argentière and for the kindness shown toward them.

Thanks are also due to Dr R. Vosters of the Université Libre de Bruxelles for his valuable advice concerning sampling procedure and to J. S. Vincent, Canadian Ph.D. candidate at the Université Libre de Bruxelles who kindly reviewed the manuscript.

MS. received I 8 December 1972 and in revised form 9 April 1973

\section{REFERENGES}

Jellinek, H. H. G. [ $\left.{ }^{\mathrm{c}} \mathrm{I} 972.\right]$ The ice interface. (In Horne, R. A., ed. Water and aqueous solutions: structure, thermodynamics, and transport processes. New York, etc., Wiley-Interscience, p. 65-107.)

Kemper, W. D., and others. 1970. Separation of adsorbed cation species as water flows through clays, by W. D. Kemper, I. D. Sills and L. A. Aylmore. Soil Science Society of America. Proceedings, Vol. 34, p. 946-48.

Lliboutry, L. A. 197r. Permeability, brine content and temperature of temperate ice. Fournal of Glaciology, Vol. Io, No. 58, p. I $5^{-29}$.

Nye, J. F., and Frank, F. C. In press. The hydrology of the intergranular veins in a temperate glacier. Union Géodésique et Géophysique Internationale. Association Internationale d'Hydrologie Scientifique. Commission de Neiges et Glaces. Symposium on the hytrology of glaciers, Cambridge, $7^{-1} 3$ September 1969, organized by the Glaciological Society.

Renaud, A. [1952.] Nouvelle contribution à l'étude du grain de glacier. Union Géodésique et Géophysique Internationale. Association Internationale d'Hydrologie Scientifique. Assemblée générale de Bruxelles, I95I, Tom. I, p. $206-1$ I.

Vivian, R. 1970. La nappe phréatique du glacier d'Argentière (massif du Mont Blanc). Comptes Rendus Hebdomadaires des Séances de l'Académie des Sciences (Paris), Sér. D, Tom. 270, No. 4, p. 6o4-06.

Vivian, R. I971. Glacier d'Argentière (Mont Blanc). Ice, No. 35, p. 6-7. 